\title{
35. VOLCANIC ROCKS RECOVERED ON LEG 6
}

William G. Melson, Natural History Museum, Washington, D. C.

\section{INTRODUCTION}

Two hydrothermally altered olivine basalts from the Philippine Sea (Hole 54.0) and one olivine dolerite from the Caroline Ridge (Hole 57.1) are described below. All three samples are from igneous basement in this area.

In addition, numerous basalt fragments recovered from the bumper sub, after drilling at Site 58 , are described. Some of these fragments which are fresh and angular are believed to be from the basement in the Caroline Ridge area; others which are more rounded and heterogeneous are believed to come from adjacent volcanic islands.

The two olivine basalt samples from Hole 54.0 are very similar and differ only in the extent of hydrothermal alteration. One sample (piece 4 ) contains 28 per cent of secondary minerals, including veins of carbonate. Both samples have grain sizes typical of flows.

The olivine dolerite from Hole 57.1 is coarser grained and is most likely a fragment from a sill or thick lava lake.

Compositionally, all three samples fall in the normative ternary olivine-diopside-hypersthene, a feature typical of 'oceanic tholeiites.' However, the mineralogy suggests they are higher in the alkalies and titania than the average oceanic tholeiite and thus will have alkaline basalt affinities.

\section{PETROGRAPHIC DESCRIPTIONS}

\section{Sample 54.0-9-1, Piece 8}

Mineralogical name: Olivine basalt.

Source body: Fragments of pillow lava.

Probable chemical classification: Olivine basalt, alkaline affinities.

Mode: See Column 2 of Table 1.

Grain size and texture: Laths of plagioclase about 0.7 $\times 0.1$ millimeter, maximum length 1 millimeter. Microphenocrysts of plagioclase and olivine (up to 1.5 millimeters maximum dimension). Olivine and groundmass extensively altered.

Texture: Subophitic with irregularly shaped patches of altered groundmass; scattered olivine granules, sparse areas composed mainly of olivine and plagioclase with minor pyroxene.
Additional noteworthy features:

1. Grain size and texture typical of that of pillow lavas.

2. Augite is tinged light reddish-brown suggesting a moderately high titanium content.

3. Most abundant alteration mineral is brownishorange micaeous mineral with high birefringence, probably a smectite group mineral.

4. Rare vesicles ( 1 per cent) filled with secondary micaeous minerals and, in some, minor carbonate.

\section{Sample 54.0-9-1, Piece 4}

Mineralogical name: Olivine basalt (hydrothermally altered).

Source body: Fragments of pillow lava.

Probable chemical classification: Olivine basalt with alkaline affinities.

Mode: See Column 1 of Table 1.

Texture: Original texture, grain size, and mineralogy obscured, but very similar to piece 8 .

Additional noteworthy features:

1. See those mentioned for piece 8 .

2. More altered than piece 8 .

3. Slightly brecciated, with calcite-filled fractures.

TABLE 1

Modal Analyses

\begin{tabular}{lccc}
\hline & $\begin{array}{c}54.0-9-1, \\
\text { piece } 4\end{array}$ & $\begin{array}{c}54.0-9-1, \\
\text { piece } 8\end{array}$ & $\begin{array}{c}57.1-4 \\
\text { piece 2 }\end{array}$ \\
\hline Plagioclase & 44 & 52 & 46 \\
Pyroxene & 26 & 28 & $29^{3}$ \\
$\begin{array}{l}\text { Alteration products } \\
\quad \text { and groundmass }\end{array}$ & $28^{1}$ & 8 & $14^{2}$ \\
Olivine & $\mathrm{n} . \mathrm{n}$. & 8 & 2 \\
Oxides & 2 & 4 & 8 \\
Chromian & Tr. & Tr. & n.n. \\
\hline
\end{tabular}

${ }^{1}$ Includes 4 per cent carbonate.

${ }^{2}$ Includes green isotropic alteration product, irresolvable groundmass material, traces of carbonate and actinolite (?)

${ }^{3}$ May include minor amount of pigeonite. n.n. = none noted. 


\section{Sample 57.1-4, Piece 2}

Mineralogical name: Olivine dolerite.

Source body: Sill or thick lava flow.

Probable chemical classification: Olivine basalt (i.e., in normative ternary olivine-diopside-hypersthene) may be higher in titanium and possibly the alkalies than average 'oceanic tholeiite').

Mode: See Column 3 of Table 1.

Texture: Conspicuous clots of large euhedral plagioclase crystals bounded by anhedra of pyroxene and olivine comprise about 20 per cent of the sample. Plagioclase laths attain a maximum length of 5 millimeters. Matrix consists of (1) ophitic areas containing olivine granules, and (2) patches of quench material rich in oxide skeletal crystals. Matrix crystal size averages 0.5 to 1.0 millimeters.

Additional noteworthy features:

1. Quite fresh, only fine-grained interstitial areas and margins and cracks in olivine are altered. Oxides, pyroxenes and plagioclase appear unaffected.

2. Main alteration is a dark green gelatinous-looking isotropic material. Rarely minute prisms of actinolite (?) occur within this material.

3 . The coarsely crystalline clots of euhedral plagioclase with granules of pyroxene and plagioclase are a distinctive feature of this sample.

4. Magnetic, chemical, and other properties of this sample should reflect primarily magmatic and cooling processes rather than later post-cooling processes.

\section{Sample from bumper sub at Site 58}

Four slides ( 1 through 4 ) were made of samples thought to have come from the volcanic basement at this site.

1. Basalt: Mainly dark-brown translucent basaltic glass which is variolitic and partly devitrified. Scattered microlites of augite and plagioclase, each comprising about 5 per cent of section. No olivine microlites occur, although a rare, highly birefringent secondary mineral replaced what may have originally been olivine. One large ( 5 by 4 millimeter) zoned plagioclase phenocryst present. Sample probably from margin of pillow lava.

2. Basalt: In order of abundance, and estimated modes, consists of (1) quenched nearly opaque mesostatis (50 per cent), (2) plagioclase and augite microlites in subequal amounts (40 per cent), and (3) plagioclase phenocrysts (10 per cent). Mesostatis is 10 per cent skeletal oxides; remainder is quench crystals of plagioclase and pyroxene and unidentifiable finer-grained material. Sample probably from near contact of sill or dike, or short distance (few centimeters) within pillow lava.

3. Olivine Basalt: Comprises about 80 per cent fresh, light-brown basaltic glass (sideromelane). Contains large phenocrysts of olivine (which contain small chromian spinel octahedra) and plagioclase. Olivine is dominant phenocrystal mineral (5 per cent) and shows strain features and rounded margins (resorbed; perhaps these crystals are xenocrysts). Crystallites of olivine, plagioclase, and augite occur in the glass. Same origin probably as 1 or 2 above.

4. Basalt: Microlites of plagioclase and augite in devitrified glass. Basalt contains angular inclusions rich in chlorite and actinolite. Same origin probably as 1 or 2 above.

Four slides (5 through 8 ) were also made of rocks thought to have come from adjacent islands.

5. Basalt: Abundant aligned plagioclase microlites in a nearly opaque extremely fine-grained quenched matrix. Sparse vesicles are filled with radiating needles of a nearly isotropic zeolite mineral. Tuffaceous material occurs on one half of section. Same origin possibly as 1 or 2 above.

6. Basalt: Highly vesicular rock largely altered to zeolite, carbonate, and possibly other secondary minerals. Originally contained olivine cyrstals now largely altered to an orange, highly birefringent secondary mineral (saponite?). Plagioclase microlites may be partially albitized. Some vesicles appear to be filled by foraminiferal ooze. Relict augite microlites are common in the groundmass. Probably from a lava flow, either subaerial or submarine, though highly vesicular nature suggests a shallow submarine flow if latter is the case.

7. Olivine Basalt: Highly vesicular rock with microphenocrysts of olivine; groundmass is mainly devitrified glass with small olivine and plagioclase microlites. Origin probably the same as 6 above.

8. Volcanoclastic Rock: Comprises basalt fragments in a lithified foraminiferal ooze. Numerous other calcareous tests present. Basalt has phenocrysts of augite and plagioclase in a tachylite groundmass. Origin in a lithified body of volcanic and biogenic detritus. 